fore, wometimes stands between the So (Exchequer) clase of Bn 2 nd the rest of Lond. Generally Rs egrees wth $\mathrm{K}$, more then with $\mathrm{Or} \mathrm{Gi} \mathrm{(Hn} \mathrm{49,}$ 3d), but it atends nenrer to the original then $K$; 800 sbove, ff. 9v, 17r. Some places where $R$ e confirms my conjectures ere mentioned sbove (e. g. Hn 94, $3 \mathrm{R}^{\%}$ ). But bow could it come to pase that Rs in common with Sc show comptrions whech are not to be found in the rest of London IrSs. (Hn i $\left.0,4^{6} .71,12^{17} .87,62^{5}\right)$ ? Wo know the onginal of the Legee Henrici to heve been left incomploto in atyle, with radimente of original conception partly altered and with traces of half expresed aftorthoughts. Pourbly the archotype of $\mathrm{HI}$ contained somo of this incomplote matter in the margin, or between the lines, and it was faithfolly copied in the mme may by the two scribes, one of whom we followed by $8 \mathrm{c}$ end the other by Ra and Lond. It was thas pomible for Re m common with So to prefor the wrong reading, while the exemplar to which Lond adhered chose the nght one.

F. LTEBERMur.

\title{
Custom and Change in Sixteenth.Century England
}

\section{A Notr ox Rosal Ecoroxac Hestosy}

Ir is one of the truest of bistorical paradoxes that the forces which resiot social change often make the change greater than it would otherwise have been. A noteworthy illustration of this is provided by the history of raral Fngland in the sixteenth century. It is impossible to say how far the lords of manors were during this period induced by a spirit of oommercial enterprise to substitute large pasture farms for small and meinly arable holdings on their estates, or how far their am wes mereiy to maintain their real incomes at their old lovei in spite of the import of American silver and the grent riso in prices: But it can, I think, be shown that the conservative landlords, whose object was to retein their old position, must heve been forced to make the more drastic chengo and wero driven to this by the influence of the very curtoms which limited their frodom of action and appeared to protect the tenents. Tenantright proved the tenents andoing. Custom acted like the barrel of a gun, which restrains the explosive and add to the effect of the explcsion.

As a rule, it appears that in the sirteenth century a large majority of the tenents on a manor wero copyholders, ${ }^{1}$ and, as Yritlend pointed ont long ago, the fired rents of the copyholder meant that, when the velue of money fell, he pooketed 'an uneamed increment, the product of Americen mines '? Now

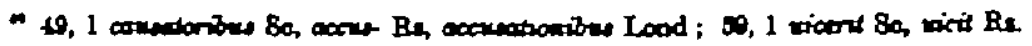
rian Land; 98, $18 X V I I$ convetly Se, $I F I$ Re, $I V$ Lood $28 ;-8$.

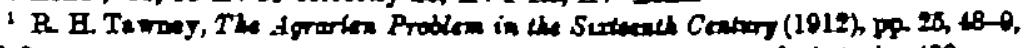


it is quite likely that, u JIr. R. E. Prothero remarks, when 'rents were raised or fines enhanced the landlord was not alwars trying to dispossess his tenant,' but thet 'as often es not he was claiming his proper share of the tenant's "unearned increment" '? Yet this is not the whole trath. The lord could only raise the rent of copyholds for a life or lives and coppholds for years to which no right of renowal was attached. Eren in these cases he could only increase the rent when the copyhold expired." But the number of copyholds which foll in during the lifetime of an incliridual lord was necessarily small. In the Discourse of the Commoniceal the bnight complains that ' in all my lifo tume I looke not that the thirde parte of my lende shall come to my dispocition, that I meyo enheunce the rent of the same; but it shelbe in mens holdinges, either by lease or by copie, graunted before wr time, and still contynuinge, and yet like to continewe in the same estate, for the most part duringe my life and perchaunce my sonnes'.5 From this it follows that a lord who mished simply to maintain his real income at its old lovel and to prerent the tenants from reaping on unearned increment at his expense, would bo obliged to rase the rents of those holdings which fell in to a greater degree than was justified by the fall in the value of money. Unable to raise the nominal rents of all his land, he would be forced to raise the real rent of some of it. Thus wes possible, because the conditions of the inarket for wool enabled the land to be used more profitably if new methods were adopted. But unhepply for the small tenants, these new methods involved consoludation and conversion of arable into pasture: they were methods the small farmer could not adopt. The ner rent represented the value of the land as used in a way in which the small holder could not use it." Thus even though the lord was conservative and only wished to preserve the old condition of things, he would be driven to radical messures which would compel the small tenents to throw up their holdings. And the compelling force would be the custom which prevented rents from boing raised except when copyholds and leases terminated.

The irony of fate was sumilar in the case of some copyholds of inheritance and some estates for life where a right of renewal belonged to the tenant. It appears that on such holdings aduris.

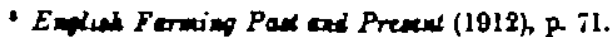

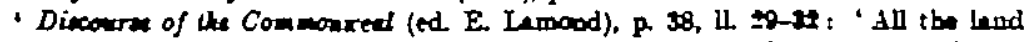

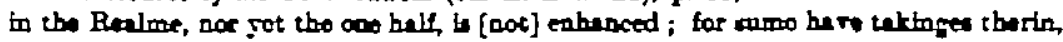

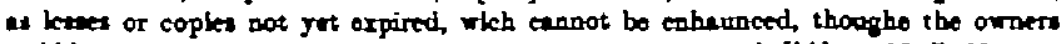
wold.'

I Ibid, \& 10, II $\neq 0-b$.

- $\mathrm{Cl}$ Cunntaghem, Grorth of Enolish Indudry (tth editton), i 461 This is probabiy tho cxplanetion of tho comphint medo in 1516 (?) thet no terme, tennement, or cattagro' can be pot ' Whthout we pare ... mare then wre are ablo to mate ' ( 1 Skpklica. tron of the Poore Common, Early Enflith Tert Soctety, p. 79) 
sion fines were frequently uncertain.7 Therefore the lord would try to iscrease his nominal income by raising fines. But, agin, being unable to do this on all the holdings, since only a fow copyholds would require renerral in one lord's lifetime, he would be compelled-if he was not to lose in real income-to raise the fines on a few holdings so much thet the increase compensated for the lose in reel rent on many other holdings es well. These fines would probebly prove too heevy for the tenant to pey, so that the land would come into the lord's hands and engrosing and conversion be faciliteted. Even if we exsume the very improbeble case thet all the copyholds on a manior of variable fines chanced to require renowal about the same time, the custom which forbede a rise of rents on copyholds of inheritence must still have tended to drive the tenents of such holdings from the land. Mr. Tawnoy understates the case when he wys that 'the edventege of the fired rent is in fact neatralised by the movesble fine'?' It is one thing to raise a tenent's yearly rent;

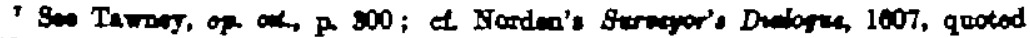
ibid, sote on P. 300.

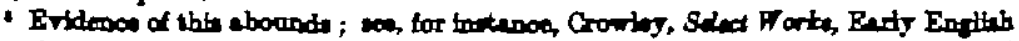

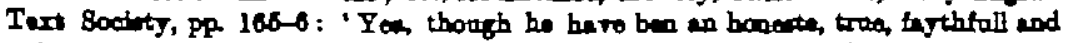

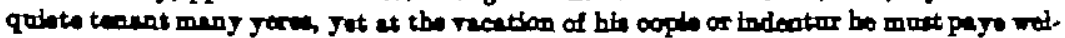

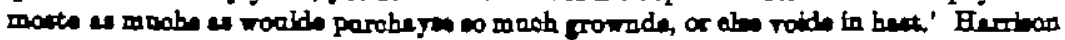

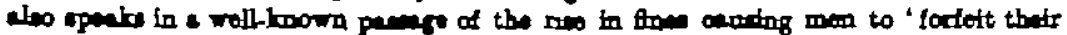

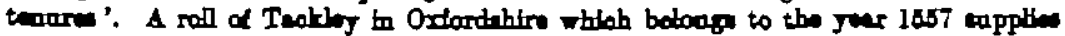

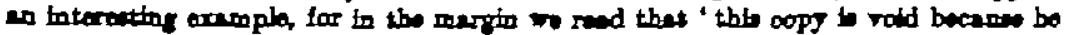

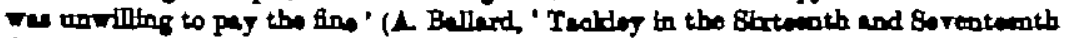

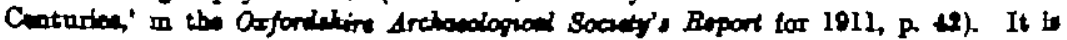

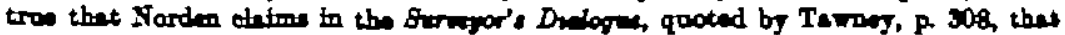

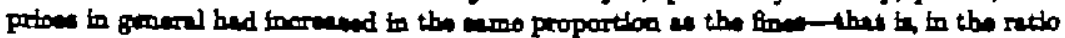

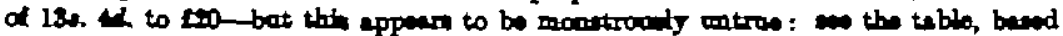

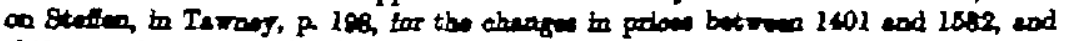

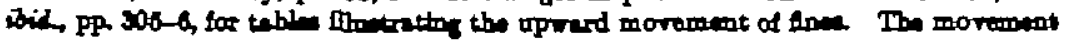

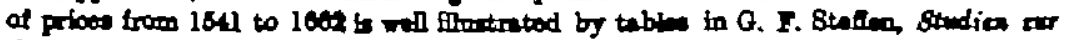

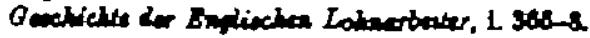

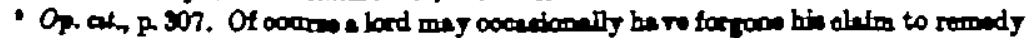

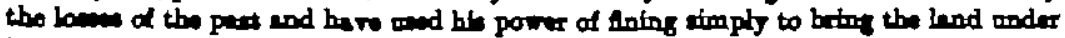

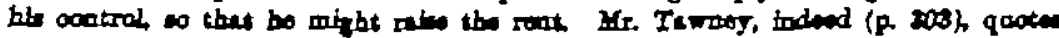

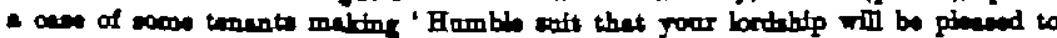

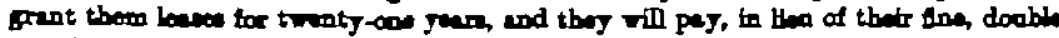

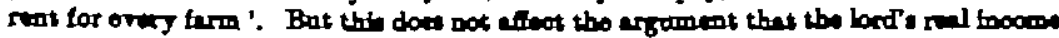

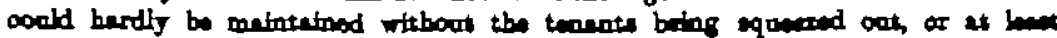

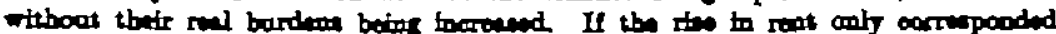

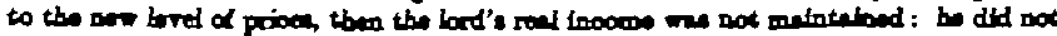

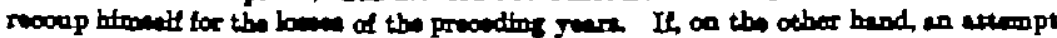

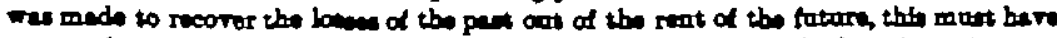

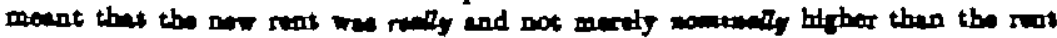

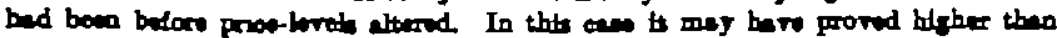

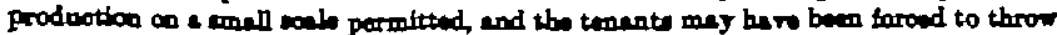

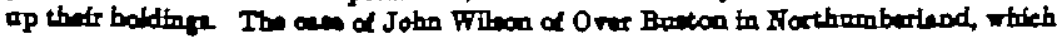

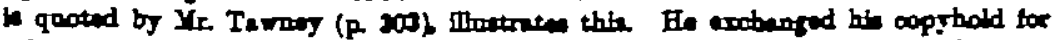

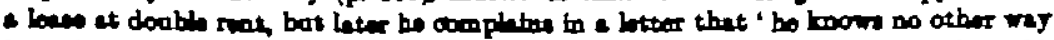

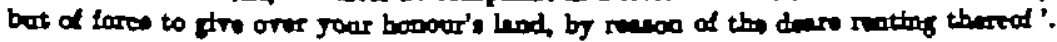


It is quite another thing suddenly to call for many yeers' arrears (f gains won through unprecedented conditions. I tenant can afford to pay an augmented rent if this increase is only proportionate to the fall in the value of money But he mey be utterly unsble to produce the capital value of the 'unearned increment' which his father had reaped and probably spent durng the years he wes in powession. The economic conditions were unlooked for : there is a note of surprise in the economic literature of the period. No man could tell that the rise in prices would contunue, thet lords would be forced to raike fines, or that it was necessery to sero against this contingency. Thus oven in this lest casothat of a menor with variable fines where all the copyholds fell in at the seme tume- the custom which protected the copyholders from an incresse in their yearly rents must have induced tenants to throw up their holdings rather then tace the bankruptcy which the increesed fines would have brought upon them. In general, the effect of the oustom was to make the conservative motives of the lord an agent in the accomplishment of radical changes.

REGLYLD Lersiad.

\section{A French Memoir on Pitt's Naval Operations of $1757-8$}

Ir packet 85 of the Chatham IISS'. in H.MI.'s Public Record Office is a Mémoire contauning the criticisms of a French offloial on the British naval operations of the years 1757-8 against Rochefort, St. Malo, Cherbourg, and othor towns. It purports to be a reply to an Englishman who had written to him on that subject; but this is probebly a derice of the writer to ercuse his treasonable conduct. Doeuments of this lind are always open to suspicion; but the present communication is of sufficient interest to warrant publication almost in extenso. It bears date 1759 and is docketed ' No. 6'. The many solecisms render it probablo that the writer was a foreigaer. Ho was almost certainly attached to the office of the Intendant at La Rochello.

\section{J. Hounerd Rose.}

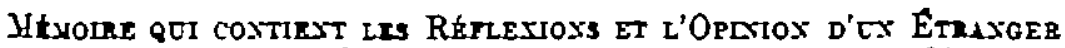

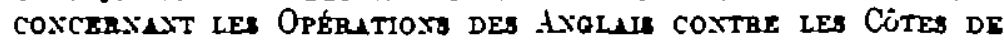
Fusice, ex Rtroxce afI SextDiexts d'cx Axolats dE sEs LuIs -

Vous etes peraudé, Ionsieur, que les defférentes operations war les Costes de France, pendant les deur dernières annees, ont produit tont l'effet qu'on s'en attendoit (si l'on excepte l'expédition contre Rochefort); que l'Anglois ne peut ni no doit conserrer aucun poste sur les côtes françaises, et, siil n'a pas réuni en entrer deas ses projets, du moins ll a dérangé le munistère de la Frence dens ses opérntione en l'obligeent de rappeler 